\title{
ARX Gene
}

National Cancer Institute

\section{Source}

National Cancer Institute. ARX Gene. NCI Thesaurus. Code C74968.

This gene plays a role in transcriptional regulation and the development of the brain. 